CLINICAL HEMORHEOLOGY, Vol. 12, p. 339, 1992

$0271-5198 / 92 \$ 5.00+.00$ Printed in the USA.

Copyright (c) 1992 Pergamon Press Ltd. All rights reserved.

\title{
CONTENTS OF BIORHEOLOGY, VOLUME 28, NUMBER 6
}

VOLUME 28, NUMBER 6

1991

A. Silberberg and A.L. Copley

A.L. Copley

P. Sourander

R. Peslin, M. Rotger, N. Delaigue and C. Duvivier

W.H. Reinhart, C. Huang, M. Vayo,

G. Norwich, S. Chien and R. Skalak

K. Ohta, Y. Fukuuchi, M. Tomita,

N. Tanahashi, S. Matsuoka and H. Takeda

C. Dong, R. Skalak and K.-L.P. Sung

K.K. Brookshier and J.M. Tarbell

G. Guiffant, J.J. Durussel, J. Dufaux and P. Roubaud

\section{Contents}

485 Editorial

487 To the Editors, Referees, Authors and Readers of Biorheology

Proceedings of the Seventh International Congress of Biorheology, Nancy, France, 18-23 June 1989. Part VII. Editors: A.L. Copley and J.-F. Stoltz

Plenary Lecture

491 Neurobiorheology. A new branch of biorheology - Historical background and current ideas

Papers

527 Compared responses of rat lungs to step volume changes and to sinusoidal forcing

537 Folding of red blood cells in capillaries and narrow pores

551 Monoclonal antibody against platelet thrombospondin decreases erythrocyte aggregation rate

557 Cytoplasmic rheology of passive neutrophils

569 Effect of hematocrit on wall shear rate in oscillatory flow: Do the elastic properties of blood play a role?

Mini-Report

589 Topological analysis of microcirculatory networks and rheological blood properties from two teleost fishes-Comparison with a sea mammal and a terrestrial mammal

595 Report on The First World Congress of Biomechanics G.W. Schmid-Schönbein-Secretary General of the Congress

597 Announcement

599 Contents of CLINICAL HEMORHEOLOGY Volume 11 , Numbers $1 / 2$ 